\section{Androgen-secreting Tumour of the Adrenal Cortex without Masculinization}

\author{
R. H. TIPTON, \\ R. G. CLARKE

\section{G. W. PENNINGTON, R. L. LUNT,}

British Medical fournal, 1971, 3, 744-745

Primary androgen-producing tumours of the adrenal cortex are comparatively rare. An adrenocortical adenoma secreting large quantities of androgens but producing minimal signs of masculinization in a young woman is reported. Fractionated androgen studies indicate the reason for this weak masculinizing effect.

\section{Case Report}

The patient, an unmarried woman of 22 years, presented with a history of irregular periods for four years. From the age of 19 she had developed scanty fine facial hairs, gained weight, and noticed a pronounced increase in her muscular power.

Examination showed minimal hirsutism. The blood pressure was $140 / 80 \mathrm{~mm} \mathrm{Hg}$. There were no abdominal striae or palpable masses. Vaginal examination showed nothing abnormal and there was no clitoral hypertrophy. The haemoglobin was $18.0 \mathrm{~g} / 100 \mathrm{ml}$ and the P.C.V. $57 \%$. The red cell mass was $32 \mathrm{ml} / \mathrm{kg}$ and the whole blood volume $61 \mathrm{ml} / \mathrm{kg}$, indicating a moderate polycythaemia. Serum electrolytes and glucose tolerance were normal. Serum cholesterol was persistently low, $90-110 \mathrm{mg} / 100 \mathrm{ml}$. Intravenous pyelography showed the left kidney to be displaced downwards and a soft tissue shadow was visible over the upper pole.

The 17-oxogenic steroid (17-OGS) and 17-oxosteroid (17-OS) outputs are shown in Table I. The 17-OS output was 10 times the normal value. Fractionated 17-OS steroids (Table II) showed that the major androgen appearing in the urine was dehydroepiandrosterone. The raised 11 oxy-17 oxosteroids suggested an adrenal origin. There was no suppression of 17-OS and 17-OGS with dexamethasone (Table III).

The I.V.P. and endocrine investigations indicated the presence

TABLE I-Preoperative Urinary 17-OS and 17-OGS Output (mg/24 hr)

\begin{tabular}{|c|c|c|c|c|}
\hline & $26 / 4 / 70$ & $27 / 4 / 70$ & 9/5/70 & $10 / 5 / 70$ \\
\hline $\begin{array}{ll}17 \text { OS } & \text { OGS }\end{array}$ & $\begin{array}{l}>152 \\
25 \cdot 0\end{array}$ & $\begin{array}{l}>185 \\
23.0\end{array}$ & $\begin{array}{l}200 \\
21 \cdot 4\end{array}$ & $\begin{array}{l}146 \\
18.1\end{array}$ \\
\hline
\end{tabular}

TABLE II-Pre-operative Fractionated 17-OS (mg/24 hr)

\begin{tabular}{|c|c|c|c|c|}
\hline & & & 9/5/70 & $10 / 5 / 70$ \\
\hline $\begin{array}{lll}\text { Androsterone } & \ldots & \ldots \\
\text { Aetiocholanolone } & \ldots & . \\
\text { Dehydroepiandrosterone } & \ldots \\
\text { 11-Hydroxy androsterone } & . \\
\text { 11-Hydroxy aetiocholanolone }\end{array}$ & $\begin{array}{l}\cdots \\
\cdots \\
\cdots\end{array}$ & $\begin{array}{l}\because \\
\because \\
\therefore\end{array}$ & $\begin{array}{r}2 \cdot 4 \\
34 \cdot 0 \\
>150-0 \\
8 \cdot 6 \\
2 \cdot 0\end{array}$ & $\begin{array}{r}1.8 \\
21.0 \\
>150.0 \\
11.6 \\
1.6\end{array}$ \\
\hline
\end{tabular}

\section{Jessop Hospital for Women, Sheffield S3 TRE}

R. H. TIPTON, M.D., M.R.C.O.G., Lecturer in Obstetrics and Gynaecology G. W. PENNINGTON, M.D., M.R.C.PATH., Consultant Chemical Pathologist Northern General Hoopitul, Sheffield S5 7AU

R. L. LUNT, F.R.C.o.G., Consultant Gynaccologist

Sheffield Royal Infirmary, Sheffield S6 3DA

R. G. CLARKE, F.R.C.S., Senior Lecturer in Surgery
TABLE III-Preoperative Dexamethasone Suppression Test (Values in mg/24 h unless Otherwise Stated)

\begin{tabular}{|c|c|c|c|c|c|c|c|c|}
\hline \multirow[b]{2}{*}{$\begin{array}{l}\text { 17-OGS } \\
17-\text { OS }\end{array}$} & \multirow[b]{2}{*}{.. } & \multirow[b]{2}{*}{$\because$} & \multirow[b]{2}{*}{$\because}$. & \multicolumn{2}{|c|}{ Control } & \multirow{2}{*}{$\begin{array}{r}\text { Day } 2 \\
19 \cdot 3 \\
113 \cdot 6\end{array}$} & \multirow{2}{*}{ 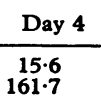 } & \multirow{2}{*}{$\begin{array}{r}\text { Day } 5 \\
16 \cdot 0 \\
268 \cdot 4\end{array}$} \\
\hline & & & & $\begin{array}{r}12 \cdot 7 \\
134 \cdot 1\end{array}$ & $\begin{array}{r}32 \cdot 2 \\
144 \cdot 0\end{array}$ & & & \\
\hline \multicolumn{4}{|c|}{$\begin{array}{lll}\text { Androsterone } . . & . . & \ldots \\
\text { Aetiocholanolone } & \ldots & \ldots \\
\text { Dehydroepiandrosterone } & \ldots \\
\text { 11-Hydroxy androsterone } & \ldots \\
\text { 11-Hydroxy aetiocholanolone }\end{array}$} & $\begin{array}{r}10 \cdot 0 \\
49 \cdot 2 \\
116 \cdot 0 \\
4 \cdot 8 \\
0 \cdot 8\end{array}$ & $\begin{array}{r}6 \cdot 6 \\
49 \cdot 2 \\
87 \cdot 2 \\
1 \cdot 8 \\
0 \cdot 7\end{array}$ & $\begin{array}{r}15 \cdot 6 \\
46 \cdot 2 \\
72 \cdot 0 \\
0 \cdot 6 \\
17 \cdot 6\end{array}$ & $\begin{array}{r}12 \cdot 4 \\
39 \cdot 4 \\
104 \cdot 0 \\
1 \cdot 2 \\
0 \cdot 4\end{array}$ & $\begin{array}{r}3 \cdot 2 \\
48 \cdot 0 \\
97 \cdot 0 \\
0.4 \\
0 \cdot 4\end{array}$ \\
\hline \multicolumn{2}{|c|}{$\begin{array}{l}\text { Pregnanediol .. } \\
\text { Pregnanetriol .. }\end{array}$} & $\therefore$ & .. & $\begin{array}{l}8 \cdot 0 \\
5 \cdot 2\end{array}$ & $\begin{array}{l}8 \cdot 2 \\
5 \cdot 3\end{array}$ & $\begin{array}{l}8 \cdot 0 \\
5 \cdot 0\end{array}$ & $\begin{array}{l}7 \cdot 4 \\
2 \cdot 6\end{array}$ & $\begin{array}{r}12 \cdot 3 \\
4 \cdot 9\end{array}$ \\
\hline \multicolumn{2}{|c|}{$\begin{array}{l}\mathrm{LH}(\mathrm{IU} / 24 \mathrm{hr}) \\
\mathrm{FSH}(\mathrm{IU} / 24 \mathrm{hr})\end{array}$} & $\because$ & $\because$ & $\begin{array}{l}98 \\
\text { Nil }\end{array}$ & $\begin{array}{l}55 \\
\text { Nil }\end{array}$ & $\begin{array}{l}43 \\
1 \cdot 3\end{array}$ & $3 \cdot 200$ & 260 \\
\hline Oestriol & .. & .. & . & 3.0 & $2 \cdot 0$ & $3 \cdot 2$ & $1 \cdot 1$ & 1.0 \\
\hline
\end{tabular}

of a left adrenal tumour. At laparotomy on 19 June 1970, an encapsulated tumour $10 \mathrm{~cm}$ in diameter was found arising from the left adrenal. A left adrenalectomy was performed. The tumour had a variegated appearance, and histological examination showed compact cells, packed closely together but showing some glomerular-like arrangement. There was no histological evidence of malignancy.

The postoperative recovery was uncomplicated. Four days after operation she had a normal period and has since menstruated regularly at monthly intervals. The muscular hypertrophy and hirsutism regressed. Within two weeks of the removal of the tumour the endocrine profile was normal. (Table IV.)

TABLE IV-Postoperative Hormone Investigations ( $\mathrm{mg} / 24 \mathrm{hr}$ )

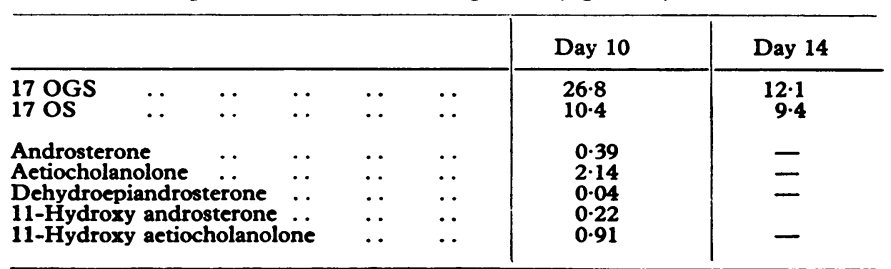

\section{Comment}

This case is of particular interest in that up to $200 \mathrm{mg} / 24 \mathrm{hr}$ of dehydroepiandrosterone was excreted in the urine and that levels in this range have usually been associated with adrenal carcinoma (Lipsett and Wilson, 1962; Mills, 1964). Furthermore, despite the high levels of urinary $\mathrm{C} 19$ steroids there were minimal signs of masculinization. Harrison et al. (1966) suggested that in a case of adrenal cortical carcinoma where the excretion of dehydroepiandrosterone was $21-25 \mathrm{mg} / 24 \mathrm{hr}$ virilization may have been prevented by a high production of oestrogens. In this case the total excretion of 17-OS was 10 times greater than in their case and the oestrogen excretion was low, indicating that a more likely explanation for the lack of virilization was the low androgenic potency of dehydroepiandrosterone and aetiocholanolone. The relative potency of androgenic steroids is difficult to assess in man, but animal experiments by Dorfman and Shipley (1956) and Aberhalden (1953) indicated that dehydroepiandrosterone and aetiocholanolone have negligible androgenic potential, while androsterone has about $10 \%$ of the potency of testosterone. Aetiocholanolone and dehydroepiandrosterone in the present case formed over $\mathbf{8 0 \%}$ of the $\mathrm{C19}$ steroid excretion.

This patient had a pronounced polycythaemia despite normal or marginally raised 17-OGS excretion. Polycythaemia is often encountered in Cushing's syndrome but is said to be unusual with predominantly androgen-producing tumours. Analysis of the series of Rapaport and his colleagues (1952), however, shows that in the adrenal tumours producing Cushing's syn- 
drome $26 \%$ of cases where the haemoglobin was reported had polycythaemia, and $15 \%$ of cases diagnosed as androgenic tumours had a raised haemoglobin.

The low cholesterol levels seen in this patient may be explained by the high androsterone levels. Androsterone when given intramuscularly has been shown to cause a sharp fall of plasma cholesterol (Mills, 1964), but the mechanism by which this occurs is unknown. The amenorrhoea associated with adrenal tumours is due to suppression of FSH, but it is interesting to note that the $\mathrm{LH}$ levels were exceedingly high.

\section{References}

Aberhalden, R. (1953). Vitamine, Hormone, Fermente. Basle, Schwabe.

Dorfman, R. I., and Shipley, R. A. (1956). Androgens. New York, Wiley. Harrison, M. T., Brush, M. G., and MacFarlane, M. (1966). fournal of Endocrinology, 34, 61.

Lipsett, M. B., and Wilson, H. (1962). Fournal of Clinical Endocrinology, 22, 906.

Mills, I. H. (1964). In Clinical Aspects of Adrenal Function, p. 174. Oxford, Blackwell Scientific.

Rapaport, E., Goldberg, M. B., Gordon, S. G., and Hinman, F., jun (1952). Postgraduate Medicine, 2, 325.

\section{Transient Dysaesthesiae and Persistent Leucocytosis after Clioquinol Therapy}

\section{S. I. TERRY}

British Medical fournal, 1971, 3, 745

The following case of transient dysaesthesiae and persistent neutrophil leucocytosis after self-medication with halogenated oxyquinolines for diarrhoea, secondary to giardiasis, is of interest.

\section{Case History}

A British helicopter pilot aged 33, working in Peru from February 1968, developed an acute episode of watery diarrhoea in October 1968. The diarrhoea was severe, up to 10 times daily, but there was no blood or mucus in the stools and there was remission of symptoms without treatment within one week, except for occasional loose pale stools usually without increased frequency.

In April 1969 he developed severe watery diarrhoea and took two tablets of Mexaform (clioquinol $200 \mathrm{mg}$ and phanquone $20 \mathrm{mg}$ ) four times daily for three days. This quickly controlled the diarrhoea, but he developed malaise, nausea, and abdominal distension, and was found to have a pyrexia of $42^{\circ} \mathrm{C}$. Also, 12 hours after starting the Mexaform he developed severe dysaesthesiae of the face and upper limbs "as though petrol had been rubbed into the skin." This burning sensation persisted for one week. His other symptoms had resolved within three days.

Since then he has had numerous similar episodes of diarrhoea after travelling to other parts of the world, each time without pyrexia, but the abdominal symptoms have been similar or less severe. Over two years he has taken 200 tablets of Enterovioform (clioquinol) and 70 tablets of Mexaform. On each occasion that he took either drug he developed painful dysaesthesiae in the face and upper limbs, which persisted for four days after ceasing medication. Diarrhoea alone or in association with his other gastrointestinal symptoms had not been associated with dysaesthesiae.

Since November 1970 he has been attending the Hospital for Tropical Diseases, London, where clinical examination showed a well-nourished man, normotensive, with no abnormal physical findings. However, stool microscopy showed cysts of Giardia intestinalis and ova of Ascaris lumbricoides, and the mean white blood cell total was $14,950 / \mathrm{mm}^{3}$ (neutrophils $70 \%$, lymphocytes $22 \%$, monocytes $4 \%$, eosinophils $4 \%$ ). The leucocytosis persisted for six months. The E.S.R. was $13 \mathrm{~mm} / 1 \mathrm{hr}$, haemoglobin $15.9 \mathrm{~g} /$ $100 \mathrm{ml}$, and the film appeared normal. Three-day faecal fat excretion was $24 \mathrm{~g}$, or $8 \mathrm{~g} / 24 \mathrm{hr}$. Five-hour urine D-xylose (25 g D-xylose orally) was $5 \mathrm{~g}$.

Hospital for Tropical Diseases, London NW1 OPE

S. I. TERRY, M.B., D.T.M.\&H., Registrar, Medical Unit
The following investigations were done in an attempt to find a pyogenic cause for the neutrophil leucocytosis: midstream specimen of urine microscopy and culture, stool culture, throat swab culture, and chest $x$-ray examination, but these were all normal. There was no evidence of other parasitic infections.

Since returning to this country the patient has been asymptomatic and his giardiasis and ascariasis have been effectively treated.

Giardiasis is a well-known cause of diarrhoea and minor degrees of malabsorption and this seems to be the cause of the patient's gastrointestinal symptoms.

\section{Comment}

It has been suggested that halogenated oxyquinolines are useful in the treatment and prophylaxis of travellers' diarrhoea, though the evidence to support this is insubstantial (Richards, 1970, 1971; Marsden and Knight, 1971). Also, these drugs are freely available to the general public without prescription as they have been assumed to have no serious side effects. Recent reports from Japan suggest that this is not so, and neurological lesions have been described (Fullerton and O'Sullivan, 1968; Sobue et al., 1971; Tsubati et al., 1971). These usually take the form of a mixed peripheral neuropathy, the striking features of which are, in order of frequency, dysaesthesiae, ataxia of gait, and muscle weakness, but optic nerve damage has also been described. It has also been reported that the onset of neurological symptoms is associated with systemic disturbance, increased white blood cell total in the peripheral blood, and a raised erythrocyte sedimentation rate (Fullerton and O'Sullivan, 1968).

The persistent neutrophil leucocytosis and transient painful dysaesthesiae in this case are assumed to be secondary to halogenated oxyquinoline therapy as the circumstantial evidence is strong.

This is the first case described in the United Kingdom, and though the frequency with which side effects have been reported in Japan may be due to some genetic predisposition (British Medical fournal, 1971), a suggested association between these drugs, the dysaesthesiae, and leucocytosis in this case raises the possibility that greater awareness of the condition will lead to more frequent recognition (Lancet, 1971).

My thanks are due to Dr. R. Knight for his advice and encouragement and to Professor A. W. Woodruff for allowing me to publish data on a patient under his care.

\section{References}

British Medical fournal, 1971, 2, 291.

Fullerton, P. M., and O'Sullivan, D. J. (1968). Fournal of Neurology, Neurosurgery and Psychiatry, 31, 543.

Lancet, 1971, 1, 690.

Marsden, P. D., and Knight, R. (1971). Lancet, 1, 854.

Richards, D. A. (1970). Practitioner, 204, 822.

Richards, D. A. (1971). Lancet, 1, 44

Sobue, I., et al (1971). Neurology (Minneapolis), 21, 168

Tsubati, T., Honna, Y., and Hoski, M. (1971). Lancet, 1, 696. 